\title{
General Psychiatry Psychology of wearing face masks to prevent transition of COVID-19
}

\author{
Lynda Jiwen Song, ${ }^{1}$ Shu Xu, ${ }^{2}$ Sabina Lingxiao Xu, ${ }^{1}$ Zhuoer Sun, ${ }^{3}$ Weizhi Liu (1D ${ }^{3,4}$
}

To cite: Song LJ, Xu S, Xu SL, et al. Psychology of wearing face masks to prevent transition of COVID-19. General Psychiatry 2020;33:e100297. doi:10.1136/ gpsych-2020-100297

LJS and SX contributed equally.

LJS and SX are joint first authors.

Received 03 June 2020

Revised 27 August 2020

Accepted 08 September 2020

Check for updates

(c) Author(s) (or their employer(s)) 2020. Re-use permitted under CC BY-NC. No commercial re-use. See rights and permissions. Published by BMJ.

${ }^{1}$ Management Division, Leeds University Business School, Leeds, UK

${ }^{2}$ Department of Biostatistics, School of Global Public Health, New York University, New York City, New York, USA

${ }^{3}$ Lab for Post-traumatic Stress Disorder, Faculty of Psychology and Mental Health, Naval Medical University, Shanghai, China

${ }^{4}$ The Emotion \& Cognition Lab, Faculty of Psychology and Mental Health, Naval Medical University, Shanghai, China

Correspondence to

Dr Weizhi Liu;

13024141970@163.com
During global pandemic outbreak of COVID19 , wearing face masks has become a focus of debate. ${ }^{1}$ In this paper, we addressed the cunning nature of COVID-19 and called for the global usage of face masks, especially for people living in low-income and middleincome countries/regions with high population density as well as high-income countries/ regions with no culture of wearing face masks.

\section{CUNNING NATURE OF COVID-19}

Are face masks useful for preventing COVID19? Recent research has shown that droplets from coughs and sneezes could be projected to 6-8 meters away, ${ }^{2}$ even further than the range of 'social distance'. ${ }^{3}$ Preponderance of evidence has indicated that mask wearing reduced the transmission of infected droplets in both laboratory and clinical contexts, and public mask wearing played the most effective role in stopping the spread of the virus. ${ }^{45}$ Thus, more countries such as the USA and the UK are reassessing their public health recommendations on wearing face masks.

COVID-19 is a 'cunning disease'. ${ }^{6}$ First, due to its high level of contagiousness, many virus carriers are spreading the virus for several days before showing any observable symptoms. ${ }^{7}$ It is hard to identify those patients who look healthy but are actually highly contagious.

Second, COVID-19 is hidden and difficult to detect. Recent research pinpointed the most contagious period of time is the first 5 days when very mild symptoms are shown, ${ }^{8}$ which is different from patients with severe acute respiratory syndrome who reach peak RNA levels in 7-10 days after they indicate symptoms.

Lastly, it is also dangerous and lethal. About $20 \%$ of the identified cases will develop into severe cases, and the mortality may vary between $3 \%$ and $4 \%$, depending on the healthcare system and location. ${ }^{9}$

In sum, COVID-19 is a more complicated virus due to its nature of presymptomatic infection, mild symptoms, long incubation period, and high mortality. ${ }^{10}$ As a result, it is extremely important to wear face masks in fighting this cunning virus. ${ }^{11}$ The earlier the prevention, the better the results, as the more hidden the symptoms or there are no symptoms, the more dangerous it could become.

\section{FACE MASKS IN LOW-ECONOMY COUNTRIES}

In some countries or regions like India and African countries based on the informal economy, people live in low-income or middle-income neighbourhoods. The prevalence of poor housing conditions with high density is distributed disproportionately in the world, according to the WHO Housing and Health Guidelines. ${ }^{12}$ Social distancing is is considered as a luxurious concept due to the high level of gathering in the community. The WHO provided detailed guidelines regarding the importance of wearing masks in situations/settings with high population density, limited facilities for quarantine, no capacity to trace contacts or perform appropriate testing and care for suspected cases. ${ }^{13}$ Therefore, an effective way to prevent oneself from catching the virus is to wear masks.

Even home-made cloth masks can be effective to some extent. Home-made cloth masks have at least minor protection against large respiratory droplets. Wearing home-made cloth masks is critical for a community due to the risk of contacting with a symptomatic COVID-19 cases. $^{14}$ Therefore, the WHO's guidance recommend that healthy people use home-made masks to protect the community, ${ }^{15}$ and the guidelines issued by the Centers for Disease Control and Prevention also regarded home-made masks as a 'last resort'. ${ }^{16}$ Data from both observational studies ${ }^{4}$ and randomized controlled trials ${ }^{17}$ similarly demonstrated the effectiveness of wearing facial masks in community settings, including low-income and middle-income countries. ${ }^{18}$

\section{FACE MASKS, CULTURAL BIAS AND STIGMA}

In the epidemic society, it is important to respect each other. Previous cultural bias 
towards those who are wearing face masks (eg, Asian people) should not happen. ${ }^{19}$ The COVID-19 is the common enemy to human beings. People wearing face masks should not be discriminated but rather should be considered as having responsible behaviour to protect themselves as well as others.

Wearing face masks has been associated with the stigma of being sick, ${ }^{20}$ and normally healthy people do not need to wear face masks to prevent diseases. This stigma might need to be changed due to the threat of COVID-19. Recent data showed a high prevalence of mass masking was feasible during the aggressive outbreak of COVID-19 in those countries without pre-existing culture of mask wearing..$^{18}$ Mental health professionals should also play an important role in dealing with stigma. ${ }^{21}$

\section{KNOWLEDGE SHARING AND EFFECTIVE PROTECTION}

Researchers recommended a rational face masks usage across countries at different risk levels. ${ }^{22}$ The WHO is already issuing guidance on face masks, which have guided many countries to take effective measures to encourage people to wear masks in fighting against COVID-19. ${ }^{11}$ For example, together with a few European countries, Austria started to make wearing face masks compulsory. ${ }^{23}$ The Japanese government posted free face masks to households. Wearing masks will work with other social distancing measures to curb the global epidemic of COVID-19. This strategy is especially important for the millions of people living in communities with poor sanitation and lack of access to clean water. Our overall success towards COVID-19 depends on the conditions of the communities with the least effective epidemic prevention.

Contributors LJS, SX and SLX wrote the first draft of the paper, which was revised by all authors. LJS and SX contributed equally. WL and LJS conceptualised the idea for this comment. LJS, SX, ZS and WL conducted literature review. All authors read and approved the final draft.

Funding This work was supported by the National Natural Science Foundation of China [grant numbers: 71772176, 71372161, 32071086].

Competing interests None declared.

Patient consent for publication Not required.

Provenance and peer review Not commissioned; externally peer reviewed.

Open access This is an open access article distributed in accordance with the Creative Commons Attribution Non Commercial (CC BY-NC 4.0) license, which permits others to distribute, remix, adapt, build upon this work non-commercially, and license their derivative works on different terms, provided the original work is properly cited, appropriate credit is given, any changes made indicated, and the use is non-commercial. See: http://creativecommons.org/licenses/by-nc/4.0/.

ORCID iD

Weizhi Liu http://orcid.org/0000-0001-6836-5522
REFERENCES

1 Greenhalgh T, Schmid MB, Czypionka T, et al. Face masks for the public during the covid-19 crisis. BMJ 2020;369:m1435.

2 David Shukman. Coronavirus: expert panel to assess face mask use by public. Available: https://www.bbc.co.uk/news/scienceenvironment-52126735 [Accessed 5 May 2020].

3 Sorokowska A, Sorokowski P, Hilpert P, et al. Preferred interpersonal distances: a global comparison. J Cross Cult Psychol 2017;48:577-92.

4 Chu DK, Akl EA, Duda S, et al. Physical distancing, face masks, and eye protection to prevent person-to-person transmission of SARS-CoV-2 and COVID-19: a systematic review and meta-analysis. Lancet 2020;395:1973-87.

5 Howard J, Huang A, Li Z, et al. Face masks against COVID-19: an evidence review. Preprints 2020.

6 Val Brickates Kennedy. Surprising traits of how COVID-19 affects patients, according to experts. Available: https://www. businessinsider.com/3-surprising-traits-of-covid-19-according-toexperts-2020-3? $r=U S \& I R=T$ [Accessed 4 May 2020].

7 Apoorva Mandavilli. Infected but feeling fine: the unwitting coronavirus Spreaders. Available: https://www.nytimes.com/2020/03/ 31/health/coronavirus-asymptomatic-transmission.html [Accessed 5 May 2020].

8 Wölfel R, Corman VM, Guggemos W, et al. Virological assessment of hospitalized patients with COVID-2019. Nature 2020;581:465-9.

9 World Health Organization. Coronavirus disease 2019 (COVID-19) situation report - 46. Available: https://www.who.int/docs/defaultsource/coronaviruse/situation-reports/20200306-sitrep-46-covid-19. pdf?sfvrsn=96b04adf_4 [Accessed 20 Jul 2020].

10 Park M, Cook AR, Lim JT, et al. A systematic review of COVID-19 epidemiology based on current evidence. J Clin Med 2020;9:967.

11 Liu X, Zhang S. COVID-19: face masks and human-to-human transmission. Influenza Other Respi Viruses 2020;14:472-3.

12 World Water Assessment Programme (Nations Unies). The United nations world water development report 2018 (United nations educational, scientific and cultural organization, New York, United States), 2018. Available: www.unwater.org/publications/world-waterdevelopment-report-2018/ [Accessed 4 May 2020].

13 World Health Organization,. Advice on the use of masks in the context of COVID-19, interim guidance. Available: https://apps. who.int/iris/bitstream/handle/10665/332293/WHO-2019-nCov-IPC Masks-2020.4-eng.pdf?sequence=1\&isAllowed=y [Accessed $20 \mathrm{Jul}$ 2020].

14 Rossettie S, Perry C, Pourghaed M, et al. Effectiveness of manufactured surgical masks, respirators, and home-made masks in prevention of respiratory infection due to airborne microorganisms. The Chronicles 2020;8:11-26.

15 World Health Organization. Guidance on wearing homemade cloth masks. Available: https://www.who.int/bangladesh/emergencies/ coronavirus-disease-(covid-19)-update/when-and-how-to-usemasks [Accessed 20 Jul 2020].

16 Centers for Disease Control and Prevention. Strategies for optimizing the supply of Facemasks. Available: https://www.cdc. gov/coronavirus/2019-ncov/hcp/ppe-strategy/face-masks.html [Accessed 20 Jul 2020].

17 Maclntyre CR, Chughtai AA. Facemasks for the prevention of infection in healthcare and community settings. BMJ 2015;350:h694-5.

18 Siewe Fodjo JN, Pengpid S, Villela EFdeM, et al. Mass masking as a way to contain COVID-19 and exit lockdown in low- and middleincome countries. J Infect 2020;81:e1-5.

19 Hillary Leung. Why wearing a face mask is encouraged in Asia, but shunned in the U.S. Available: https://time.com/5799964/ coronavirus-face-mask-asia-us/ [Accessed 20 Jul 2020].

20 Saddleback Valley Unified School District. Coronavirus (COVID-19) frequently asked questions. Available: https://www.svusd.org/ uploaded/SVUSD_Department_Files/Student_Services/Forms/20202021/Coronavirus_FAQ.pdf [Accessed 20 Jul 2020].

21 Prasad SK, Karahda A, Singh P, et al. Role of mental health professionals in dealing with the stigma attached to COVID-19. Gen Psychiatr 2020;33:e100298.

22 Feng S, Shen C, Xia N, et al. Rational use of face masks in the COVID-19 pandemic. Lancet Respir Med 2020;8:434-6.

23 Austria makes masks compulsory as protection debate shifts. Available: https://www.ft.com/content/f68f3063-5024-4654-9389bcc7ee1efd8e [Accessed 6 May 2020]. 


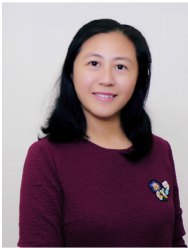

Lynda Song received her PhD in Organizational Management from the Hong Kong University of Science and Technology in 2005, and received master's degree in psychology from East China Normal University in 2000, and bachelor's degree in psychology from East China Normal University in 1998. She has been a Professor of Management Division, Business School, University of Leeds, UK since 2019, and currently is the Academy of Management Member and the International Association of Chinese Management Research Founding Member. She also serves as the Head of Management Division. Her main research interests include leadership, human resource management, and industrial and organizational psychology. 